\title{
ISOCRATES AND HIS WORK ON RHETORIC AND PHILOSOPHY
}

We now turn to Isocrates, a complex figure, whose reputation, appreciation and position in the tradition of rhetoric and philosophy are often debated. Focus of the following discussion will primarily center on the way in which Isocrates frames himself within this intellectual tradition and how he becomes conceptualized as a representative of a philosophicalrhetorical tradition that sees itself as separate from (though not necessarily opposed to) the kind of rhetoric epitomized in the figure of Lysias. Isocrates is an author and teacher of the elite, a writer rather than performer, a philosopher rather than entertainer.

Isocrates' works contain a substantial amount of information about his life. With hindsight we might say that the decision to draw attention to his persona in his writings gave him a privileged position to craft his own reception and reputation in an almost unprecedented way. ${ }^{\mathrm{I}}$ We learn about his family background and education, about his struggles after the Thirty, ${ }^{2}$ about his inability to pursue a political career, ${ }^{3}$ and, last but not least, about his contributions to the Athenian intellectual life of the time. ${ }^{4}$ These biographical snippets do not, of course, necessarily tell us much about the historical Isocrates, ${ }^{5}$ but they give us a sense of how Isocrates might have

\footnotetext{
I An excellent and detailed overview of Isocrates' life and work is provided in López Cruces and Fuentes González (2000). For a brief overview of Isocrates' biography, see Laistner (I927), I I-I5; Mirhady and Too (2000), I-3. Halliwell (I990), 42-59 provides an insightful discussion of Isocrates' own treatment of character in the 'encomiastic biography' of Evagoras in the Evagoras.

2 Antidosis I6I-5. ${ }^{3}$ To Philip 8I-2, Panathenaicus 9-I I.

${ }^{4}$ Isocrates happily lists his students in Antidosis 93-IOI who have later become (he claims) respected men in the city.

5 The rhetoric of Isocrates' self-characterization is the subject of Too (I995).
} 
wanted his image to emerge from his works and support the building blocks of his philosophy. The direct tone and firstperson address of many of his discourses also enhance his image as a teacher and didactic philosopher, something that will become an important element of his reception in postfourth-century BCE rhetorical tradition. Furthermore, Isocrates seems to have regarded his work as a comprehensive whole and often refers back to, or comments on, his previous writings, explicitly denying any significant change in the character of his work. ${ }^{6}$ We might say, then, that Isocrates had developed a strong sense of ownership over his work and his literary output is planned with extreme care, thus creating (and controlling) the interpretative paradigms for its evaluation. In order to put his thought in context and elucidate what kind of contributions he expected to (and did) make, it is important to unpack the way he talks about his work and to situate it within his current intellectual landscape. This will also help us get a better sense of Isocrates' role and later prominence in rhetorical theory.

Even though few philosophers today would consider Isocrates as their intellectual predecessor, ${ }^{7}$ he was quite probably among the first to open a school of philosophy in Athens, ${ }^{8}$ and portrays himself as proposing a radical alternative to the philosophical thought of his time. ${ }^{9}$ That Isocrates conceived of a philosophical enterprise very differently than (say) Plato did, is clear from his writings and this topic has received increased attention in recent scholarship. ${ }^{\text {IO }}$ What exactly Isocrates meant with philosophia and the kind of impact he expected to exert with his work are still, however, hotly debated. In this context,

${ }^{6}$ This view is extensively defended in Too (I995), Io-73 (esp. 34-5). It is worth remembering that Isocrates had a very long life and so the stability of his thought might strike us as particularly remarkable.

7 Yet few would perhaps be as dismissive as Marrou (I965), I3 I-3.

8 The foundation of the school is often dated to the 390 os BCE. Cf. Blass (I892), I7-I 8; Kennedy (I980), 3I. Ostwald and Lynch (I994) argue that Antisthenes' school was the first one founded in Athens, closely followed by Isocrates.

9 Isocrates as the only alternative to contemporary philosophical schools that all traced themselves back to Socrates is discussed extensively in the following chapter.

Io See e.g. Nightingale (I995), chap. I; Halliwell (I997); Schiappa (I999). 
we should bear in mind two considerations: first, there was no fixed philosophical discipline at the time he was writing and the concept of philosophy itself was widely contested. As a result, we should read Isocrates' engagements with philosophy and rhetoric with an open mind and realize that the philosophical context in which he was writing and teaching was more fluid and dynamic than what we are used to today. ${ }^{\text {I }}$

The following discussion in this chapter is divided into three larger subsections: the first part will focus on Isocrates' take on wisdom literature and looks at the way he fashions his own discourse as a response to contemporary educational needs for reform: to replace the poetic tradition with his own discourses. The second section investigates Isocrates' discussion of prose writing, the training of writing skills as constituting a wider formative principle of education, and the political goals of such writing practices. The third section thematizes Isocrates' approach to philosophy: how and under which terms could he be reasonably regarded as belonging to the philosophical tradition? These three strands - the poetic, prosaic-political and philosophical - are to my mind essential for appreciating the way in which Isocrates himself paves the way for his subsequent reception as an Attic writer, educator and a crucial backbone to the rhetorical tradition. My investigation shows in later chapters, surely as a surprise to some readers, that Plato and most later critics take over rather uncritically and endorse Isocrates' self-presentation and so accept his central position in the history of rhetoric. Yet, despite the fact that Isocrates himself is in full control over his image and reception, he remains an exceptional - if not even marginal - case, hard to pin down and force into generic categories of ancient texts that we have gotten used to since. Hence we notice this recurring insecurity about Isocrates, whether he ought to be regarded an Attic orator or philosopher. ${ }^{\text {I2 }}$ Even though Plato's Phaedrus has already shown a direction, in its

I Nightingale (I995), chap. I.

I2 Halliwell (1997) is essential reading for discussions on Isocrates' philosophy and rhetoric, and has in many ways prompted the present inquiry. 
characteristically suggestive way, for how to appreciate Isocrates' role in the rhetorical tradition, it will take another four centuries until Isocrates' position in the rhetorical tradition is reiterated with greater detail and fixed by Dionysius of Halicarnassus' clear expression of him as the pioneer of 'true philosophy' for rhetoric.

\section{I Challenging the Poetic Tradition}

When discussing poetic discourse, Isocrates appears mainly interested in the function of poetry in society, that is to say the role of Homer and Hesiod as teachers and educators, creators of the image of a virtuous (Hellenic) man, and the way their works have been received and interpreted as providing useful advice for 'the everyday' or for the 'monumental moments' in life. ${ }^{\mathrm{I}}$ In other words, his aim is not so much to develop an account of poetics, but rather to focus on those aspects of the role of poetry in society that merit mention and discussion in the context of education. ${ }^{\text {I4 }}$ Isocrates' polished style, which aims to provide an example of the writing of a cultured and virtuous citizen, is a testament to his program of using poetic texts as (moral) examples in educational settings. Similarly to poetic works that would be quoted and discussed in classrooms as providing guidelines for different situations,

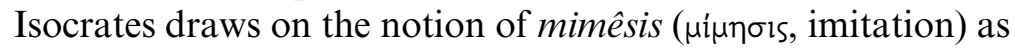
a paradigm for using his own works. ${ }^{15}$ Isocrates is not looking to question or puzzle his readers or students as Gorgias might

${ }^{13}$ For more detailed discussions of Isocrates' engagement with the poetic tradition, see Papillon (I998). An insightful and provocative interpretation of Isocrates' concept of poetics is recently put forth by Halliwell (20I I), 285-304.

${ }^{14}$ Halliwell (20II) seems to be disappointed in Isocrates' concept of poetics ('to accept the consequences of that stance for the valuation of poetry is to share Isocrates' remorselessly prosaic view of the world', 304) because he does not take into consideration Isocrates' very specific and education-driven agenda when mentioning poetic works.

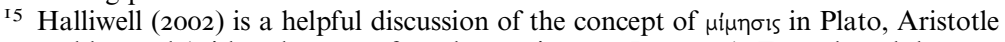
and beyond (with only a very few observations on Isocrates). Even though he puts forth persuasive and reasonable arguments for avoiding the translation of the Greek $\mu i \mu \eta \sigma / s$ as 'imitation', for the sake of convenience the following discussion will use the two - mimesis and imitation - interchangeably. 
have done with his writings, or as Plato makes his students 'wonder' by means of aporiai. Instead, Isocrates seems to devise his speeches as works that function as models for imitation for his students and readers, and would thus give concrete practical examples of written compositions. Thinking through the tradition of poetry seems therefore to be an essential stage in the process of setting up the science of speech and thought.

In his writings, Isocrates also exhibits a polemical attitude to poetry that suggests a more competitive attitude to the role of poetry in society. In some passages he indicates that his work is set in (a constructive) dialogue with poetic practices; in others, he overtly opposes his work to that of the poets. This ambivalence is crucial to Isocrates' argument, for he needs to show the benefit of those aspects of poetry that he will be associating with his own genre, and draw attention to the shortcomings that make poetry an inadequate or outdated carrier of these virtues and benefits that Isocrates' discourses promise to deliver. Examples of the first, positive, attitude can be found, for instance, in his Antidosis (46-7), where he compares his prose writing to poetry, contrasting his particular (poetic) way of writing explicitly to other kinds of prose, mostly courtroom speeches. ${ }^{\mathrm{I}}$ There, Isocrates appeals to the authoritative position of poetry that he expects will soon be occupied by his own works. Examples of the critical attitude to the poetic tradition can be found in his Evagoras and To Nicocles, speeches which are closely associated with the poetic and particularly with the gnomic tradition. ${ }^{17}$

Isocrates criticizes two types of poetic works in particular the praise encomium and gnomic poetry. These are also the two that are arguably closest to his own philosophical

${ }^{16}$ Papillon (I998) explores Isocrates' constructive use of the poetic tradition, and argues persuasively that in shaping his discourse Isocrates is heavily drawing on some of the most prominent elements of poetic discourse: Isocrates makes use of a variety of styles (from the impressive Pindaric, to the smooth Bacchylidean and pedagogical/advisory Solonian), he makes use of myth, self-correction and priamel as ways to shape his discourse, and lays emphasis on the ethical dimensions of poetry.

${ }^{17}$ See Alexiou (2010), 28-37 with bibliography. 
project, ${ }^{18}$ and his comments on these two kinds of poetic production serve to map the boundaries of his own discourse. In the Evagoras, where Isocrates elaborates the idea of the prose encomium, he claims that while poetry is charming and pleasurable to listen to (Io), the words and ideas used are misleading, invented and/or wrong (II, 36). ${ }^{\text {I9 }}$ Poets have escaped these accusations because they use verse, which enchants and draws attention from content to the form of poems. The underlying implication seems to be, however, that poets are no longer fulfilling their function in society as educators, for by telling lies they are not providing the best models of behavior and are thus not able to serve society as genuine teachers of virtue. Prose writings cannot hide their faults or lack of depth in the way poetry can with the help of meter. Excellent prose writers must be, therefore, more coherent and to the point than their poetic counterparts. This produces - so Isocrates argues - overall better content, and as such ought to be preferred in educational contexts to traditional poetry.

Isocrates offers also another explanation for the need to go beyond existing poetic works. In multiple passages of To Nicocles he discusses gnomic poetry and argues that the education available for the rulers ought to be different from that of the general public. According to him, poets have focused primarily on the needs of the majority and do not provide useful advice tailored specifically for rulers, showing thus another instance where poetry might have an impact on society, but pointing out that this impact is limited and needs to be supplemented by Isocrates' own contributions. The advice given to rulers and their subjects is, according to Isocrates, necessarily different and this is evident from the behavior of the masses who, despite knowing the best course of action or what would make them

${ }^{18}$ Hunter (20I4), 77 suggests, for example, that 'Isocrates clearly aims to write a prose version of such improving works [as Hesiod's Works and Days]'.

19 A very similar idea is expressed in Panegyricus (I68), where Isocrates draws a sharp

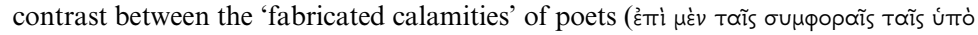

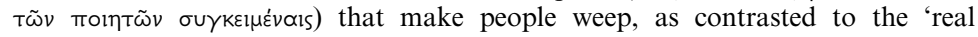
suffering' ( $\left.\dot{\alpha} \lambda \eta \theta_{l v} \dot{\alpha} \pi \dot{\alpha} \theta \eta\right)$ experienced in war that people are far less bothered about. See on this passage also Halliwell (2002), 2 I2-I5. 
better men, do not act accordingly and instead 'in every way take pleasures in things that are contrary to their best interests' (45). As a consequence, the masses are not interested in those most

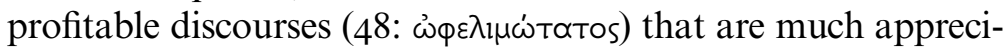
ated by the rulers, but instead follow those recommendations that abound in fictions (48: $\mu \cup \theta \omega \delta \varepsilon \dot{\sigma} \sigma \alpha t o s) .{ }^{20}$ Isocrates' political prose promises to fill this gap and provide useful advice for the educated elite alone. In other words, the prose that Isocrates has to offer his students is vastly different from the simplicity and wit that seemed to have made Lysias' work so popular. The two writers, then, represent opposites in the educational elite context in Athens. For Isocrates, contrasting his work with these two kinds of poetic works has helped him, first, specify the particular contributions his discourse aims to make and, second, narrow down the audience for whom he envisions his advice to be particularly relevant. In sum, Isocrates challenges the aims and means of the poetic tradition and by moving beyond it he demonstrates how his own discourses meet the expectations of society more adequately. In particular, he claims to provide an education that is defined by its usefulness and that prepares its students for the practicalities of life and politics.

\subsection{Isocrates on Prose}

Isocrates is one of our most thorough ancient advocates of written prose. Having established his difference from poetic discourse, Isocrates dedicates substantial effort to drawing further distinctions between his own works - collectively referred

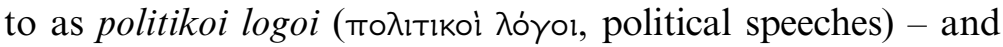
those of other prose writers by promoting the uniqueness of his ideas and emphasizing his contributions to philosophy. Given that prose had just started to become an established mode of philosophical and rhetorical writing, ${ }^{2 \mathrm{I}}$ and given his

${ }^{20}$ The examples Isocrates evokes here are Homeric epics and early tragic poetry $(48-9)$.

${ }^{21}$ For discussions on the relationship between poetry and prose, see Goldhill (2002); the collection of essays in Yunis (2003); Graff (2005). 
educational program which prioritized the ability to express oneself in written form, Isocrates had to provide an innovative approach to philosophical prose in order to stand out and legitimize his school. When discussing other prose authors or works, Isocrates mainly uses two approaches: he either corrects the methods and/or aims of their works, as they have failed to fulfil what they set out to do (or what the generic expectations demand they do), or he provides lists of various kinds of prose writings as established and well-known genres in the order of importance, where his own works always rank as superior to others.

The first approach is best exemplified in his Helen and Busiris. The method of analysis in both speeches is similar: Isocrates examines either a previous speech (Busiris) or a topic that has been subject to multiple interpretations (Helen), comments where others have gone wrong and gives his own version or solution. ${ }^{22}$ In both of these works, other - either previous or contemporary - authors seem to have misunderstood the particularities of the genre they were writing in and ended up promoting, because of their ignorance, the opposite to what they set out to do: Gorgias' Helen, supposed to be an encomium, turned out to focus mainly on the faults of Helen, ${ }^{23}$ Polycrates' Busiris, aimed to be a defense turned out to be an accusation, ${ }^{24}$ and Polycrates' other work, the accusation of Socrates, would have been received by Socrates more as an encomium than an accusation. ${ }^{25}$ By drawing attention to the mismatch between the generic expectations and the actual content of their discourses, Isocrates paves the way for his own supposedly coherent expositions on the topic. ${ }^{26}$

${ }^{22}$ Correcting previous writers: Helen $\mathrm{I} 4-\mathrm{I} 5$, Busiris 9; offering his own interpretation: Helen I6, Busiris Io.

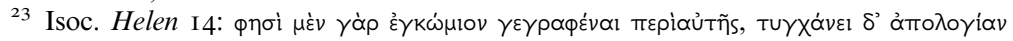

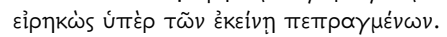

${ }^{24}$ Isoc. Busiris 4-5.

25 Isoc. Busiris 6: 'Socrates would be as grateful to you for your accusation as to any

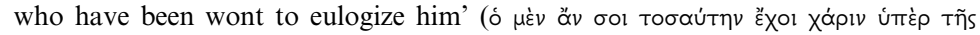

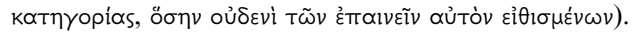

26 And so Isocrates' Helen focuses only on those aspects of her representation that can be wholeheartedly praised, and avoids getting caught up with topics that associate 
Helen in particular has a programmatic aspect to the work. The first part of the discourse gives us Isocrates' critical assessment of the current educational scene and the prose encomium that follows cannot be read in isolation from what precedes it. The potential of prose writings to tackle serious and fundamental topics had not been, at least according to Isocrates, properly exploited thus far. Hence, Isocrates' treatment of Gorgias and Polycrates entails not only, or not simply, criticisms of their generic misunderstandings of what encomia should do. More than that, Isocrates seems to suggest that they have failed to understand the true function and opportunities for serious learning that could be imparted through prose. Isocrates demonstrates instead how someone with his training and education would be able to spot inconsistencies, not be persuaded by misleading arguments, and capable of composing in the very genre better than those who had done so previously. ${ }^{27}$ Furthermore, by evoking philosophers and rhetoricians (like Polycrates), Isocrates makes a pointed gesture towards a context within which he expects his work to appear and be of relevance. In other words, he is targeting the potential students of philosophers and rhetoricians by demonstrating the failures of both of these groups as helpful educational role models. By contrast, his own teaching and writings do not deceive the recipient, they follow closely the clearly expressed aims of his discourse and, because of this coherence of purpose, his works will be more useful and beneficial for anyone interested. In other words, through his criticisms of Gorgias and Polycrates, Isocrates shapes an image of his work as serious, morally coherent and demanding.

Another way Isocrates discusses prose literature, and his own position within it, is by way of constructing lists of 'kinds of prose'. He does so in prominent positions of his Antidosis and Panathenaicus, works that qualify as perhaps Isocrates'

her with negative fame. Livingstone (200I), I2 talks about the 'pure' genre of encomium. Cf. also Zajonz (2002), I45.

27 This is of course (and not coincidentally, as I will argue below) closely reminiscent of Socrates and his criticisms of 'Lysianic speech' in the Phaedrus. 
most extensive expressions of his educational and philosophical program. The lists of prose genres given in both works differ slightly, and this might be explained by the caveat provided at the beginning of the first list, where Isocrates

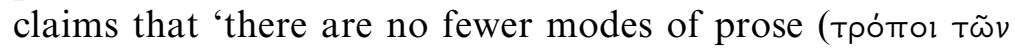
$\lambda o ́ \gamma \omega v$ ) than of verse' (Antidosis 45), thus implying that these lists are quite arbitrary and could easily look different. In Antidosis (45) he outlines six prose genres, ${ }^{28}$ emphasizing in

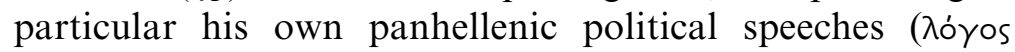

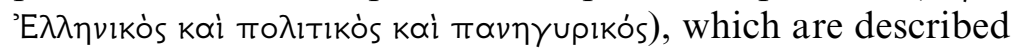
as encompassing all the compositional techniques one needs to know for creating a piece of work in any other genre. In Panathenaicus (I-2) Isocrates lists five prose genres, ${ }^{29}$ once again saving his own panhellenic discourse to last. ${ }^{30}$ In both lists, Isocrates sets up a particularly explicit opposition between his own work and that of courtroom writers. In the Antidosis, the latter are singled out as a natural point of comparison to Isocrates' writing and teaching program $(47-50) .{ }^{3 \mathrm{I}}$ This comparison comes at a crucial section in the discourse and is referred back to in the following passage as having given 'the whole truth about my power, philosophy or profession, however you want to call it' (50: $\pi \varepsilon \rho i \mu \dot{\varepsilon} v$ oũv

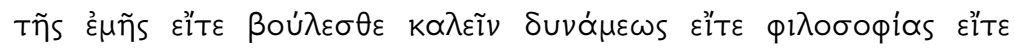

${ }^{28}$ The six prose genres are the following: (I) Researches in the genealogies of the

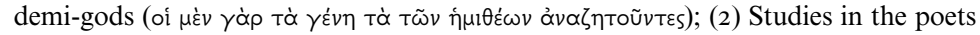

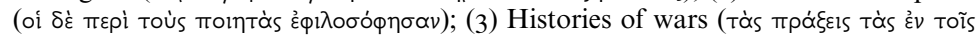

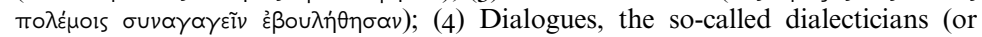

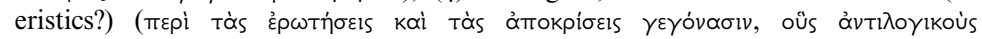

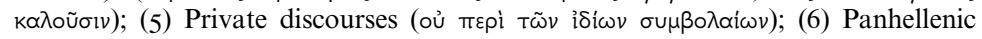

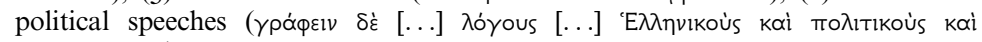

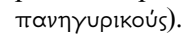

29 The five prose genres: (I) logoi which deal with mythological themes; (2) logoi about marvelous or fictitious themes; (3) logoi about historical events; (4) logoi written in plain style and aimed at persuasion in law courts; (5) logoi which give advice on the true interests of Athens and of the rest of the Hellenes, written in a rich style full with arguments.

30 Panathenaicus 2.

${ }^{31}$ E.g. 'many desire to become students [of Isocratean discourses], thinking that those who excel in this field are wiser and better and of more use than men who speak well

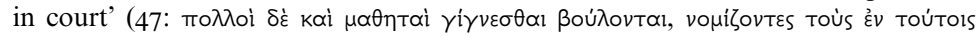

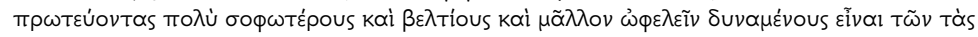

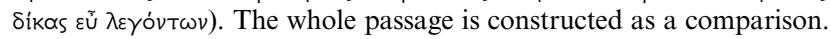




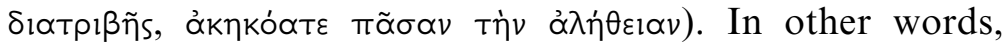
courtroom writers are depicted as among the most significant opponents of Isocrates' work.

In the Panathenaicus, Isocrates' criticism appears more generally directed towards the so-called sophists, a group who will be shown below to encompass in Isocrates' view a wide array of intellectuals, including philosophers. However, when reflecting on his youth and career, he once again compares his decision to dedicate himself to the study and writing of panhellenic matters to those who deal with private contracts and courtroom matters (II). In the opening section of the work, Isocrates gives some clarification about the characteristics of their writing. These are works that 'give the impression of having been composed in a plain and simple manner and having no embellishments, which those who are clever at lawsuits urge our young men to cultivate'. ${ }^{32}$ Should we not think here of Lysias, or at least those who are influenced by the style and writings of Lysias? ${ }^{33}$ Walberer has argued that Lysias, who might have just finished his composition of the Olympiacus (which Walberer regards as authentic), is the opponent Isocrates reacts against in the Panegyricus (I I-I 2). ${ }^{34}$ There, Isocrates discusses men who expect most elaborate writing to have to meet the standards of courtroom pleas, which essentially means in this passage the use of simple style. ${ }^{35}$ In fact, it seems that we can connect most references to the kind of rhetoric which Isocrates disapproves of to the plain style of Lysias or his followers. Isocrates' fierce criticism of this type of writing might suggest its widespread popularity and, therefore, could be taken as an additional confirmation of the

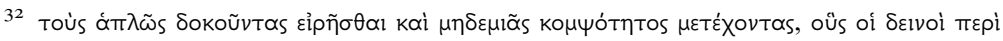

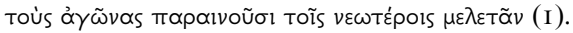

33 As far as I can see, only Norlin (I968), 373 suggests that the section might refer to Lysias.

34 Walberer (I938), 55-60.

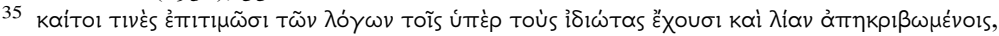

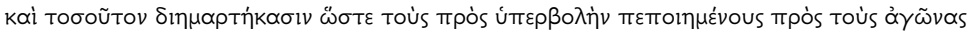

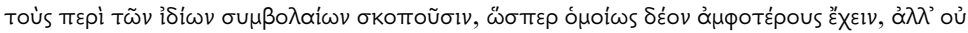

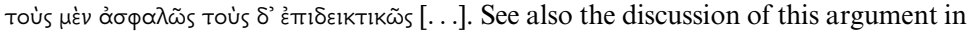
Wilcox (I943a), I I9-20. 
statement made in the beginning of Plato's Phaedrus, which referred to Lysias as one of the most successful and popular

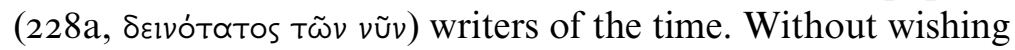
to push this point too hard, it does seem that the kind of writing and style that Lysias had come to embody by the fourth century BCE represented a major point of reference and criticism for Isocrates' own educational and philosophical program.

Going back to the two lists provided in the Antidosis and Panathenaicus, the slight differences should not come as a surprise after Isocrates' own emphasis on the arbitrariness of providing them, but what is perhaps more striking is the fact that in neither of the lists does Isocrates mention philosophical writings as a separate category. Pfister has drawn attention to this absence in his article, suggesting that Isocrates might have neglected philosophical literature as a separate genre in order to avoid associating it with the Academy. ${ }^{36}$ His discussion provoked the response of Wilcox who has attempted to explain away this surprising absence by suggesting that both the Antidosis and the Panathenaicus actually do make reference to philosophical genres; in the former it is mentioned as 'ques-

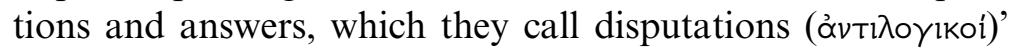
(45) and in the latter under the wider term 'logoi about marvelous or fictitious themes' ${ }^{37}$ Wilcox's discussion is persuasive in so far as he aims to establish that Isocrates refers in both works to a kind of philosophical writing, namely the Socratic dialogues, but we need not assume that this would capture a readily understandable and fixed generic category of philosophical writing. Moreover, in her commentary on the Antidosis, Too suggests that what Wilcox was keen to regard as a reference to a philosophical category is more likely to characterize sophistic works and, perhaps, those of Protagoras and his followers in particular. ${ }^{38}$ But perhaps there is a third way to explain the absence of philosophical works from the list. What if Isocrates never conceived of philosophy as a

${ }^{36}$ Pfister (I933), 458. $\quad 37$ Wilcox (I943). $\quad 3^{8}$ Too (2008), I I9-20. 
specific genre, as something that should be written down? What if philosophy was a term that Isocrates used first and foremost to refer to the (primarily oral?) practice of teaching, thinking and deliberating? It is a well-known and often stated fact that the concept of philosophy was unfixed and widely used to denote a range of different intellectual activities at the time. Yet, as this debate shows, there still lingers an expectation among scholars of finding it conceptualized in similar terms as we have since come to know it from the philosophical tradition, as a separate and self-standing written genre that Isocrates could not have been able to avoid mentioning in his work. In order to further investigate the possibility that philosophy was not conceived as a written practice or fixed written genre by Isocrates, ${ }^{39}$ let us take a closer look at Isocrates' use of philosophia in his works.

\subsection{On What Is and What Is Not Philosophy}

Aside from describing his discourse through comparisons with other genres, Isocrates also makes explicit claims about how he views his work and its effect on Athenian society. These remarks are often made jointly with his references to philosophy, a term with which he often characterizes his intellectual output. Even though Bons has argued that Isocrates' use of (rhetorical) terminology is not as technical and specific as it is among subsequent writers, ${ }^{40}$ the following analysis of Isocrates' use of the three terms - sophist (бoфıтrn's), rhêtôrl

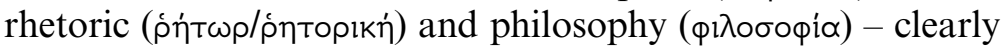
suggests that Isocrates formed distinctive interpretations of these notions and that he frequently uses them to refer either

39 Cf. Halliwell (I994), 223 who argues that philosophia became 'associated with individuals and schools of thought that aspired to comprehensive understanding of the world' and 'the world conceived as the totality of all reality'. Nightingale (I995), chap. I explores how it came about that Plato won the 'contest' for the notion of philosophy and has ever since determined the reception of Isocrates who is primarily referred to as a rhetorician.

$4^{\circ}$ Bons (I996), 4-5. 
to himself in relation to other intellectuals or to contemporary professionals and rivals.

Let us start with the concept of the 'sophist'. There are a few passages where бофıбтn's is used in a wider sense to refer to a 'wise man', ${ }^{4}$ but in these sections either the context or the qualifying words make it clear that Isocrates has in mind the

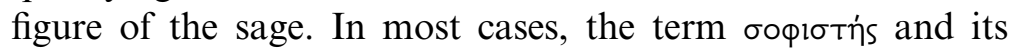
cognates occur in Isocrates' works in a negative sense. ${ }^{42}$ While Isocrates frequently uses this notion to distance his own writings from those he calls the 'sophists', 43 it remains somewhat vague throughout his works whom he considers a sophist in the first place. There are, of course, the usual suspects such as Gorgias, Protagoras and other itinerant teachers, who are included in this category. ${ }^{44}$ But we also see those listed among sophists who are now in contemporary scholarship often grouped together under the controversial label of Presocratic philosophers (Antidosis 285). There are two kinds of criticisms that Isocrates brings against the sophists most often. First, he reproaches sophists for their teaching practices and he seems to be particularly offended by the low pay that these 'sophists' ask from their students (see especially Against the Sophists 3-4). And even if some of the sophists were famous for charging large sums for their teaching, Isocrates argues that their wealth has brought no good to Athens or to themselves.

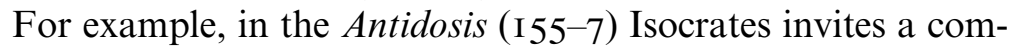
parison between himself and Gorgias, whom he regards as the most successful and wealthy sophist (of all time), but who never contributed to the city's wellbeing and at the time of his death did not leave behind a large inheritance. Contrary to the itinerant sophists, whom he describes as parasites with no home or serious commitments, Isocrates claims to have

${ }^{4 I}$ E.g. To Nicocles (13), Antidosis (235, 3I3).

${ }^{42}$ Curiously, Eucken (I983), 7 argues for the opposite case.

43 They are explicitly contrasted to Isocrates and regard Isocrates as a rival (whom they want to misrepresent) in Antidosis (2, 4), Panathenaicus (5). Sophists' activity as totally different from Isocrates' is stated or implied in Antidosis (I48, 2 I5), Panegyricus (3), Panathenaicus (I8). Sophists as different with regard to their management of finances are mentioned in Antidosis ( I55, I57).

44 Explicitly in Helen (2 and 9). 
contributed to the 'common cause' and this should be welcomed by his fellow citizens (Antidosis I 58). ${ }^{45}$ His criticism of their political uselessness is closely connected to their intellectual faults. In his educational manifesto and protreptic Against the Sophists, Isocrates maps out the contemporary educational scene and reserves the term sophists for the previous generation of intellectuals, who had 'set themselves up as being

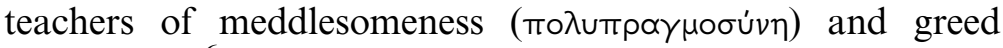
$(\pi \lambda \varepsilon \circ v \varepsilon \xi i \alpha)^{\prime} .{ }^{46}$ The distinguishing characteristic mentioned there is their narrow-mindedness: these sophists had been focusing on specific vocabulary and trying to teach their students success in law courts through this nit-picking activity. ${ }^{47}$ The second major criticism is the futility of their practice. Indeed, criticisms of the sophists are frequently associated with their lack of seriousness. In the Antidosis (268) and Helen (2-6), sophists are those who have pushed theoretical speculation to the extreme, to the extent of appearing ridiculous and bringing no profit whatsoever to their students. Depicted as unprincipled, unskilled and unable to manage their affairs (both in a financial and intellectual sense), they might even appear as relatively harmless. ${ }^{48}$

45 In a recent article, Thomas Blank (2014) argues that Isocrates did not in fact charge any fees from the Athenians and as such offered a 'public service', thus legitimizing his expectations of receiving public recognition for his services. Though in many ways an attractive suggestion, there seems to be very little to support it: his argument rests solely on his reading of a passage from the Antidosis (I64-5), which does confirm that he was accepting fees from foreigners, but says nothing about taking money from Athenians. This does not really mean that he did not - it is simply not what Isocrates is concerned with demonstrating in the passage. On Isocrates' school fees, see further Ostwald and Lynch (I994), especially 596 where they state that Isocrates' fees were modest in comparison to those of the famous sophists.

46 References to 'ancient sophists' are also made in Antidosis $(268,285)$.

47 This section is very obscure; see Böhme (2009), I 94.

${ }^{48}$ The note at the end of Panegyricus (I88-9) seems to be clearly addressed to sophists. That eloquence or knowledge of the means of eloquence itself is not 'dangerous' is thematized in Antidosis (236-7), that the influence of sophists can be minimal in Against the Sophists (I4), or ineffective in To Philip (I3). In one passage (Antidosis 197), Isocrates even shows awareness of the fact that his practice might be easily confused with the sophists and in another passage of Antidosis shows himself to be sympathetic to their cause and mentions the "common prejudice

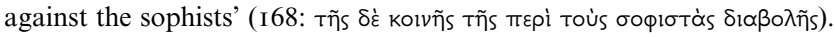


Yet, Isocrates also shows how damaging such individuals can really be. A very common reference to the sophists in Isocrates is reserved for those who are slandering his person and have thus a devastating impact not only on his general reputation, but on the Athenian educational scene more generally. This is stated at the beginning of the Antidosis, where he claims to have been long aware of the damage that the sophists have been trying to inflict on his person by associating him

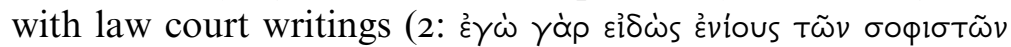

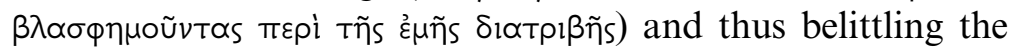
topics and approach he had taken in his discourses. ${ }^{49}$ In general, under the broad notion 'sophists' Isocrates refers both to those whom Plato and the subsequent tradition would call 'sophists' and to those later labeled as philosophers (and Presocratic philosophers in particular) whom he seems to fashion as homogeneous representatives of a tradition of philosophical thought that strongly differs from Isocrates' understanding of the notion 'philosophy'.

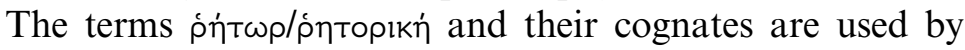
Isocrates mainly in the sense of 'public speakers' or orators who perform speeches and take an active part in politics. Isocrates suggests that this is the category in which some of his pupils can be counted, thus clearly implying that rhetoric occupies a significant role in his teaching. ${ }^{50}$ Yet, at the same time, Isocrates does not refer to himself as a rhetorician and in one passage in particular emphasizes that he should not be

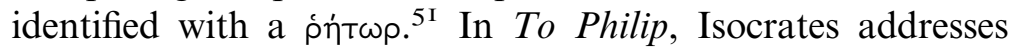
Philip and asks the latter not to be surprised if Isocrates, 'being neither a military commander nor an orator ( $\rho \hat{\imath} \tau \omega \rho)$ nor any other person of authority' (8I), has expressed himself more boldly than others. Isocrates then goes on to explain why he

49 The ancient controversy around Isocrates' law court writings is recorded in D. H. Isocrates $\mathrm{I} 8$.

$5^{\circ}$ We find this usage in On the Team of Horses (7), Against the Sophists (9), On the Peace (5), Antidosis (30, I05, I36, I38, I85, 200, 23 I), Panathenaicus (2), Plataikos $(3,38)$, To Philip (2).

5I This is surely largely due to the fact that Isocrates is not a politician and does not speak in the assembly. 
had decided not to pursue the career of a public orator and, in contrast to the quarrelsome qualities he describes one as having to develop in an oratorical context, he emphasizes his

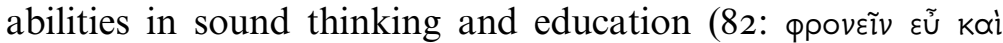
$\pi \varepsilon \pi \propto 1 \delta \varepsilon \tilde{U} \sigma \theta \alpha 1 k \alpha \lambda \tilde{\omega} s)$ that are paramount to his being able to advise Athenians, Hellenes and the most distinguished of men

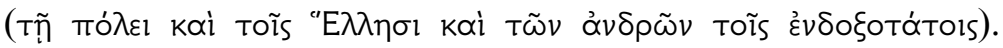
Isocrates seems to say that instead of devoting himself solely to public performances as an active public orator (i.e. politician), he has instead laid more emphasis on training his thought and cultivating general intellectual abilities that are manifested now in his ability to use written discourses to advise men who are confronted with difficult decisions. It seems that this distinction is closely related to the contrast between oral and written discourses, the ṕntopes being representatives of the oral and Isocrates' work representative of the written discourse. ${ }^{52}$ But this is perhaps the result of a more fundamental difference between Isocrates' teaching and the orators: compared to the orators, whose principal area is public speech, ${ }^{53}$ Isocrates' teaching has a far wider scope, ${ }^{54}$ and this is why his students can become professionals in a variety of areas (e.g. historians, generals and, indeed, orators).

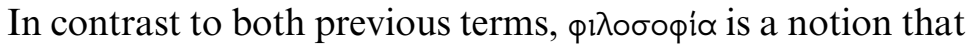
Isocrates associates closely with his own discourses, the concept and its cognates being used far more frequently throughout Isocrates' corpus than the cognates of either ṕं

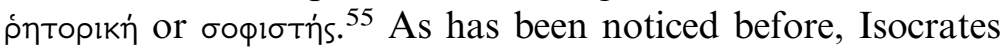

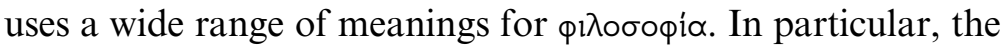
following five thematic clusters seem to be especially strongly represented in his use of the term: ${ }^{56}$ (I) philosophy as a serious

52 Isocrates addresses this explicitly in To Philip (25), and Nicocles (8). In To Philip (29) Isocrates seems to associate prejudices against sophists with those that are commonly held against written speeches.

53 Or rather, public policy as decided in the assembly and council.

54 The contrast between Isocrates' conceptions of philosophy and oratory is set up in Against the Sophists (2I).

55 I count altogether ninety occurrences of $\phi_{1} \lambda$ oo ${ }^{2} \phi_{i \alpha}$ against thirty-six occurrences of фं

${ }^{56} \mathrm{Cf}$. the similar approach to Isocrates' notion of philosophy in Timmerman (I998). 
study, (2) philosophy and practice, (3) philosophy and false philosophy, (4) philosophy and teaching, (5) philosophy as a broad intellectual discipline. All of these categories are essential to Isocrates' conception of philosophia and they all contribute to a general understanding of philosophia as a practice or activity that is primarily undertaken in an educational environment for a practical purpose (e.g. preparation for public life), rather than a kind of solitary act of thinking done for its own sake that could translate into a piece of written work. ${ }^{57}$

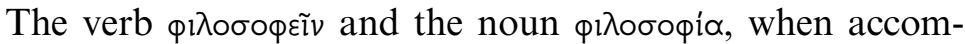

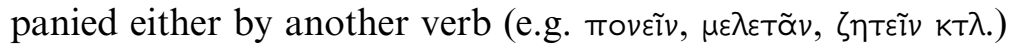

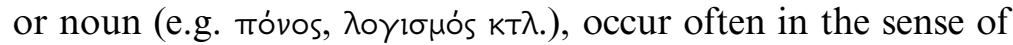
serious study that is crucial for understanding the important problems at stake. ${ }^{5}$ However, Isocrates also makes it clear that the mere contemplation of and search for theoretical solutions is not enough and in some passages he introduces a contrast between philosophy and actual practice, both being crucial to good practice. This contrast is most explicitly expressed in To Nicocles, where Isocrates argues that in order to get a thorough understanding of things under examination, one should approach these things by experience as well as by

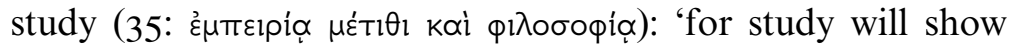
you the way, but training yourself in the actual doing of things will give you power to deal with affairs' ${ }^{59}$ Isocrates' advice to the king clearly suggests that a good understanding is reached through theoretical study (philosophy) and practice or habituation. Elsewhere, however, Isocrates debates the attribution of the notion of 'philosophy' to describe those only engaged in theoretical pursuits, and reclaims the notion for his own allencompassing practices that are beneficial in practical ways to society at large. In the Antidosis, for example, Isocrates

57 It is surprising that in her book on ancient notions of 'theory', Nightingale (2004) barely touches upon Isocrates' contributions to this debate. Isocrates is also conspicuously absent in Yunis' (2003) volume on literate culture.

${ }^{8}$ For example in Panegyricus (6, I86), Antidosis (247), To Philip (29), Panathenaicus (I I), On the Peace (5).

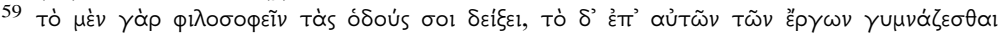

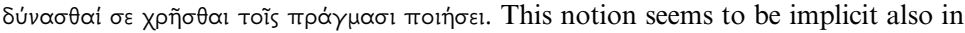
his self-evaluation in the Antidosis (I62). 
explains how his teaching helps cultivate ppóvnors (27I-87) and one of the crucial requirements for this goal, he maintains, is to understand the advantage of his approach. ${ }^{60}$ In this section (285) Isocrates expresses his particular annoyance with the following people:

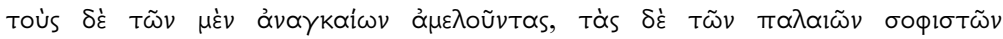

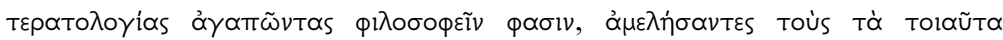

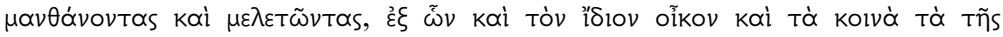

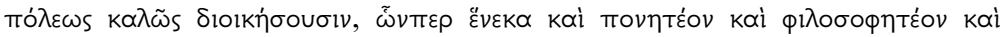

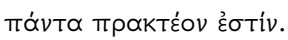

They characterize men who ignore our practical needs and delight in the mental juggling of the ancient sophists as 'students of philosophy', but refuse this name to those who pursue and practise those studies which will enable us to govern wisely both our own households and the commonwealth - which should be the objects of our toil, of our study, and of our every act.

There are many interesting aspects to Isocrates' statements here: most obviously, Isocrates claims that there is general confusion about who should be counted a philosopher and who should not. ${ }^{6 I}$ It is generally acknowledged that in the fifth and fourth centuries BCE the term 'philosophy' and its cognates were far more fluid terms than by the end of the fourth and the early third century BCE when philosophical schools had started to dominate and define research. ${ }^{62}$ To what extent this fluidity of tradition lies behind Isocrates' comments here is difficult to tell. It certainly seems from this passage, however, that an interpretation of philosophy as a solely theoretical pursuit had started to gain more prominence as the dominant (technical) use of the term 'philosophy', and that Isocrates' notion of philosophical activity would appear in this context too broad and unspecific. In a section preceding this one

6o The Isocratean notion of ppóvๆors and its difference/similarity to both Plato and Aristotle has not been much discussed in the literature. I find T. Poulakos' (2004,

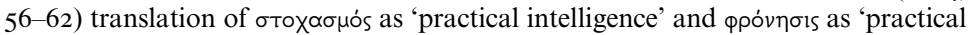
wisdom' misleading and altogether obstructing, rather than improving, our understanding of these notions. I regret that I have not been able to fully consult Roser's recent dissertation (2019), part of which is dedicated to exploring the concept of phronesis in Isocrates.

6I Cf. Antidosis (2 I5, 285), Letter to Archidamus (15), Helen (6), Panathenaicus (263).

${ }^{62}$ See, for example, Nightingale (I995), chap. I with bibliography. 
(Antidosis 284), Isocrates argues that this confusion has arisen from a fundamental misconception about the notion of 'benefit' or 'advantage' in philosophy, and has thus influenced the way in which philosophy's position in society is understood and exploited. Finally, despite Isocrates' language in this passage, those 'ancient sophists' who make a profession out of

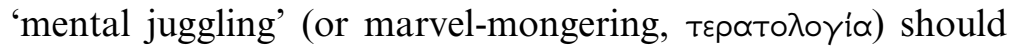
probably be understood as referring to (what we would now call) Presocratic philosophers, who had been associated with this strictly theoretical interpretation of philosophy (see also above). Contrary to the sophists, whose teaching was the result of an essentially pragmatic need for law court practices and who could thus not be rejected on the grounds of being detached from the actual pragmatic needs of society, Isocrates has elsewhere referred to Presocratic philosophers in a similar way to his description of the 'ancient sophists' here. $^{63}$ It seems, then, that Isocrates is consciously labeling proponents of a tradition of philosophy, which focuses primarily on theoretical speculation, as sophists, while at the same time inculcating a complete revision of the term to fit his own educational and philosophical paradigm. Isocrates argues that these sophists who call themselves (theoretical) philosophers have misled people about the true aims and use of philosophy, thus creating a misconception about philosophy as a superfluous practice unable to benefit society. It is, according to him, high time to reclaim the notion of philosophy from these sophists who thrive in paradoxical and unhelpful thoughts,

${ }^{63}$ In the Helen, Isocrates seems to consider (what we would call) Presocratic philosophers together with sophists. He starts his list of sophists with Protagoras (2: öøtıs

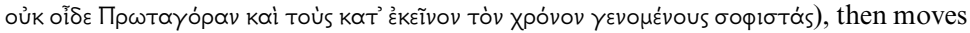
on to the philosophical works of Gorgias, Zeno and Melissus; the latter two of the list have become standard names in Presocratic philosophy. The entire group is

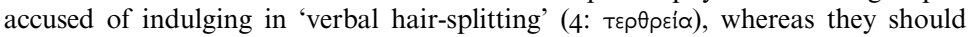
guide their students towards the truth and the practical affairs of government,

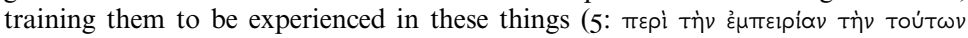

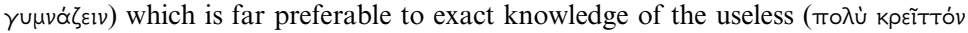

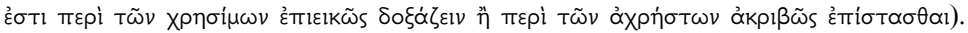
Furthermore, Eucken (1983), esp. 44-56, sees Isocrates' Helen as very closely engaged with the philosophical positions of Antisthenes, Plato and Socrates. 
and are negatively contrasted to Isocrates' pragmatic interpretation of proper philosophy. ${ }^{64}$

Isocrates' positive definition and exposition of philosophy is most clearly expressed in his Antidosis. Even though he has explained his understanding of the term in various previous passages of the work, by evoking parallels from physical training or talking about the different professions of his pupils to give an idea of his encompassing treatment of the subject, he comes to give a definition of philosophy in section 27I that is worth quoting in full:

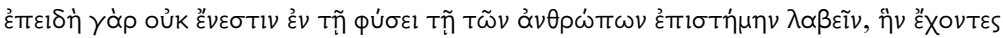

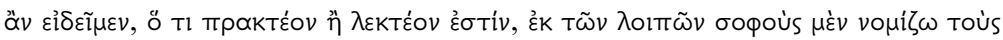

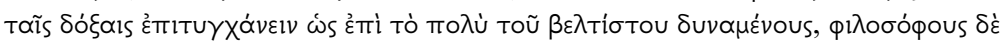

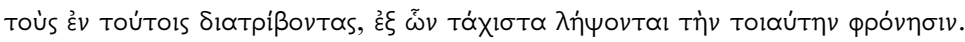

For since it is not in the nature of man to attain a science by the possession of which we can know positively what we should do or what we should say, in the next resort I hold that man to be wise who is able by his powers of conjecture to arrive generally at the best course, and I hold that man to be a philosopher who occupies himself with the studies from which he will most quickly gain that kind of insight.

In this one compressed sentence, Isocrates explains the fundamentals of his interpretation of philosophy in a way that is intelligible to different audiences, from the theoretical sophist to an active politician or layman. Isocrates argues that knowledge is unattainable for humans and thus that every kind of theoretical activity that aims to produce infallible and systematic knowledge is futile and unproductive. Even though he does not bring further evidence to bear in this passage, elsewhere in the work Isocrates invokes sophists (a group which also includes those called philosophers today, ${ }^{65}$ possibly also the Socratics) as a proof for this sentiment. According to Isocrates, sophists claim to work towards formulating fixed

${ }^{64}$ Most commentators on Isocrates do not take his claims to philosophy seriously and interpret Isocrates' discussion as focusing on rhetoric instead. This general reluctance to consider Isocrates in any way philosophically relevant is perhaps particularly surprising in Too (1995) and (2008), whose focus is unyieldingly fixed on Isocrates as a rhetorician. An exception is Schiappa (I999), I62-84.

65 Cf. Kerferd (I950); Schiappa (I999), 67-82. 
principles and arguments that would result in systematic knowledge, but end up proposing solutions that are unacceptable and also in disagreement with each other: oi $\mu \dot{\varepsilon} v$ $\gamma \dot{\alpha} \rho$

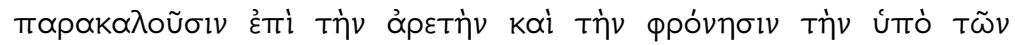

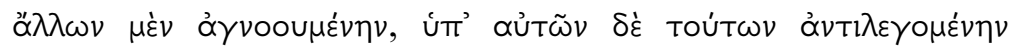
(Antidosis 84). Isocrates maintains in another passage of the work that it is not appropriate to 'call philosophy something that does not profit us in the present, either for (improving) our speaking or our actions' (266). Instead, he would call 'this kind of exercise gymnastics of the soul and a preparation for phil-

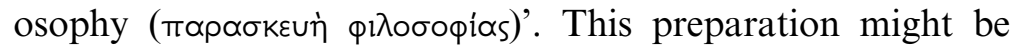
useful, as anything learned at school (266-7), to sharpen the minds and train the learning of students (265), but it should not become the sole object of their attention and students' minds should not 'be stranded on the speculations of the ancient sophists' (268), who make different claims about the ontological status of the world. The examples mentioned Empedocles, Ion, Alcmaeon, Parmenides, Melissus and Gorgias - are all from (what we now call) Presocratic philosophy and Isocrates describes them as a group that tried to render observations in the physical world to a select number of substances, ${ }^{66}$ and eventually engage in speculations about their interrelations through theoretical arguments. Isocrates rejects this tradition wholesale with his claim that this kind of knowledge is not accessible to human beings. Having made this statement and rejected the concept of philosophy as a strictly theoretical study relying on proofs, Isocrates automatically frees himself not only from the demands of this philosophical tradition, but also from any further necessity to provide more detailed or systematic argumentation to support his claims.

Instead, Isocrates argues that a true philosopher is someone who, having understood the limits of human mind, will turn his energies to studying good practice and widespread opinions

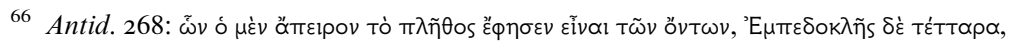

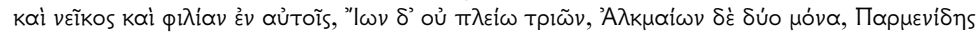

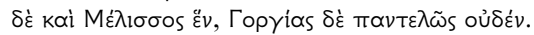


that have been verified over the course of human (Greek) history. ${ }^{67}$ Philosophers, as Isocrates claims in the passage quoted above, are those who are most experienced in this kind of study and are able to determine the best possible practice most frequently and quickly. How is this achieved without relying on theoretical arguments and sound methodologies? ${ }^{68}$ Isocrates gives three main methods that can be used: striving towards speaking well, persuading others, and a desire to seize

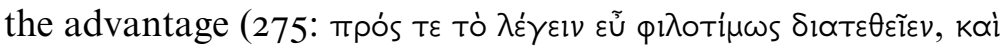

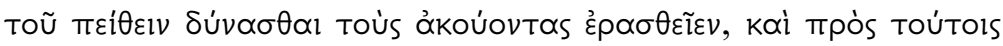

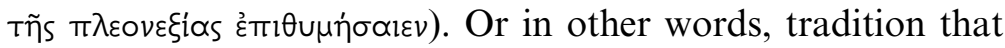
leads to forming a good moral character, which, in turn, works towards benefiting society. Isocrates explains all three aspects in detail. With regard to the first point, he argues that whenever someone has set their mind to speaking or writing honorable discourses these will be devoted 'to the welfare of man and our common good' (276). In this case, one will select actions and deeds of remarkable men and, by preparing the discourse, will thus profit oneself by becoming familiar with praiseworthy thoughts and actions (277). Isocrates argues that through this kind of training the man who is closely familiarized with his outstanding ancestors 'will feel their influence not only in the speech he has at hand, but also in other actions of his life' (277). Speaking well means, then, that by using models that have been proven by tradition to be valuable (no need to engage in theoretical discussion about these time-tested models) one tries to reach the level of these models through imitation. In other words, history and proven deeds will be used as criteria for preparing a discourse that meets the expectations of Isocratean philosophy: it will cultivate one's mind

${ }^{67} \mathrm{Cf}$. also Panathenaicus 32, where Isocrates explains what constitutes the 'educated' man.

${ }^{68}$ Cooper (I985) summarizes (from an unabashedly Platonist perspective) many of the concerns that contemporary philosophers, heirs of the tradition of philosophy that follows Plato's conceptualization of philosophical pursuit, will inevitably have when trying to find philosophically satisfactory answers to this question in Isocrates. See also Halliwell (1997), who argues that Isocrates' thought remains disturbingly at the 'first order level' and shows a profound lack of self-examination. 
and, at the same time, provide role models for active emulation throughout one's life. ${ }^{69}$

The second point, persuasion, is discussed in relation to character. In an almost anti-Aristotelian fashion, ${ }^{70}$ Isocrates claims that 'only those fixed on philosophy have failed to

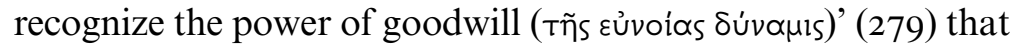
can be achieved through presenting a trustworthy and appealing character. ${ }^{7 \mathrm{I}}$ Therefore, Isocrates concludes, 'the stronger a man's desire to persuade his hearers, the more

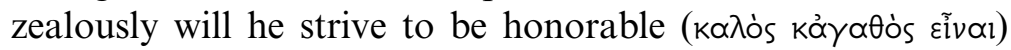
and well regarded by his fellow citizens' (278). The general pressure to have a good reputation which helps, when necessary, justify one's conduct, will provide the motivation needed to cultivate an overall honorable image of oneself. Furthermore, while all the theoretical elements of argumentation - probabilities, proofs and other kinds of persuasive

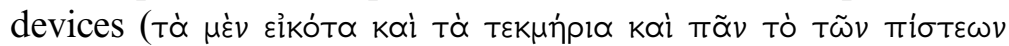

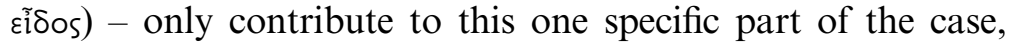

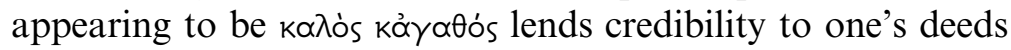
as much as to one's words (280). In this way Isocrates draws attention once again to his claim that training in successful self-presentation involves a training of character and intellectual abilities in such a way that will, eventually, lead to developing a virtuous character. In fact, elsewhere Isocrates also refers to his teaching as a broad training of the soul, ${ }^{72}$ or as an art of the mind, conceived as parallel to gymnastics, the instruction of one's body. ${ }^{73}$ Philosophy in this Isocratean sense seems to encompass a variety of other areas, and Isocrates explains how good training in astronomy, mathematics and geometry, to name but a few, might enhance the students'

${ }^{69}$ Cf. Batstone (1985), I07.

$7^{70}$ Aristotle argues in Rhetoric I356a that when persuasion occurs through character

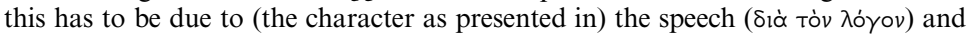
not through the preconceived idea of the speaker. Aristotle's position is, thus, the exact opposite to what Isocrates claims in this passage.

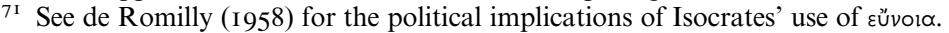

${ }^{72}$ In To Nicocles (5I), where he lists his teaching among his competitors to show that in a broad sense they all aim to give guidance about how to discipline the soul.

73 Antidosis (18I, I83). 
potential when they arrive at philosophy as the final goal of their educational training (Antidosis 26I). ${ }^{74}$ Note that Isocrates is always careful to evoke philosophy in educational settings and as an intellectual activity that serves a wider purpose of cultivating a 'proper' citizen. Philosophy is not really a goal in itself. ${ }^{75}$

The breadth of Isocrates' philosophia is also on display when he talks about his teaching methods. Isocrates suggests that his students might have multiple areas of specialization depending on their natural endowments and that in his school everyone can freely pursue different career paths and get proper support from the teacher who is going to enhance their knowledge and abilities in these different fields (Antidosis I86-8). ${ }^{76}$ In other words, contrary to a specialized philosophical school which concentrates on developing theoretical arguments about, say, the ontological status of the world, Isocrates' school trains the students in a wide variety of specializations, thus cultivating their minds and abilities more generally, as well as giving a concrete focus on their chosen field of study. Furthermore, it seems that Isocrates not only endorses multiple specializations for students, but regards philosophy as giving rise to multiple cultural and political institutions. This is stated in his Panegyricus, where Isocrates discusses various festivals of Greece and argues that philosophy is really the source for Athenian cultural supremacy:

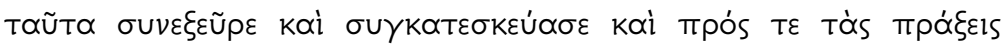

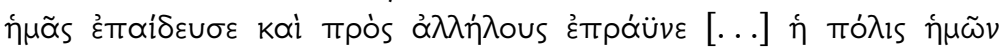
$\kappa \propto T \varepsilon ́ \delta \varepsilon 1 \xi \varepsilon v(47)$. On the one hand, this appears to be a polemical

${ }^{74}$ Philosophy seems, then, to be simultaneously the final goal of education as well as the actual practice of acculturation.

75 In this sense, I believe Isocrates is talking about something completely different than what Schiappa (I995) suggests when he tries to rehabilitate Isocrates' position in the canon of philosophy by referring to him as a representative of (philosophical) pragmatism.

${ }^{76}$ This could be supported by the surprising variety of political sentiments of Isocrates' students who do not conform in their allegiance to either democratic or aristocratic/oligarchic structures. See Harding (I973), I39. This approach seems to have resonated among later interpreters of Isocrates. See, for example, Cicero $D e$ orat. 3.9.35: discipulos dissimiles inter se ac tamen laudandos, cum ad cuiusque naturam institutio doctoris accommodaretur. 
claim, suggesting that previous traditions of philosophy (the Presocratics and/or earlier sophists) do not amount to proper philosophy. On the other hand, Isocrates is in this passage once more reinforcing the image of his philosophical project as the first comprehensive and all-encompassing training of the mind, one that must be seen in close relation to contributions made to the polis more generally. To push this thought further, it might be argued that Isocrates' philosophy remains deliberately a rather loose and undefined concept, and Isocrates shows no willingness to develop strict logical structures of thought or methodology that would compel all students to come to the same kind of results or state of mind.

Perhaps Isocrates' rejection of the rhetorical handbook tradition could be regarded as another side to the same argument about the pitfalls of applying fixed structures and/or rules of thought to a creative process such as learning. Given the previous discussion of Isocrates' philosophy, which is best conceived as a broad intellectual practice that makes a virtue out of the relative vagueness of the concept, it is easy to see why Isocrates would disapprove of the practice of writing and using technical handbooks for educational purposes. ${ }^{77}$ Isocrates makes this clear in his programmatic work Against the Sophists, where he criticizes teachers 'who have themselves failed to notice that they are bringing a fixed art as an example

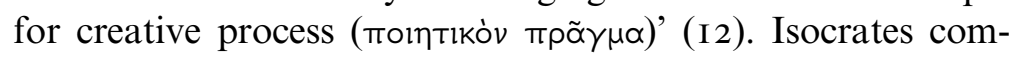
pares the art of using letters to the art of discourse $(\log o i)$ : the first is a fixed and unchangeable process where 'we continually and invariably use the same letters for the same purposes', whereas in discourses 'what has been said by one speaker is not equally useful for the speaker who comes after him' (I2). Furthermore, Isocrates expresses strong reservations about the ability to teach virtue or, more generally, to simply turn any willing student to virtue and philosophy. According to him,

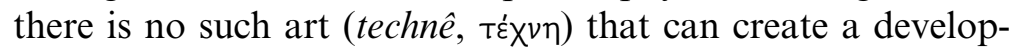
ment towards virtue and justice in 'depraved natures' (2 I: Toĩs

77 Cf. Bons (I996), I I-I3. 


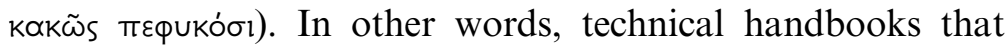
depict teaching and learning as a straightforward matter, where the student will improve simply by memorizing and following the rules provided in these books, are misleading and can hardly deliver what they boast to be able to do: to create experts or educated men from all their students. There are multiple references to Isocrates' aversion to the handbook tradition in his works, even though they are less explicit than his statements in Against the Sophists and Antidosis. ${ }^{78}$

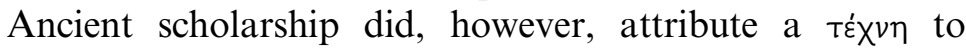
Isocrates and, despite the relatively widely held view among modern scholars that Isocrates did not participate in the handbook tradition, this position has been recently challenged. ${ }^{79} \mathrm{It}$ is true that Barwick, who argued against the Isocratean TÉx $v \eta$, was forced, rather uncomfortably, to admit several stages of misunderstanding among ancient theorists (including Cicero and Quintilian) in order to maintain his point and at the same time give a plausible rationale for the existence of ancient accounts of Isocrates' $\tau \dot{x} \chi \nu \eta{ }^{80}$ The main thrust of his argument is based on the fact that TÉx $v \eta$ in the fourth century BCE could mean both a 'handbook' and a 'polished speech', and that the later understanding of ${ }^{\prime} \varepsilon \dot{x} v \eta$ in a strictly technical sense created a confusion among rhetoricians, who misread a passage from

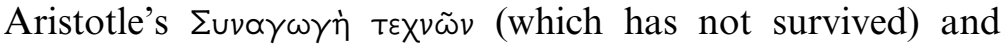
assumed that Isocrates also wrote a $\tau \varepsilon \dot{x} \chi \eta$ (even though no actual work survives). Papillon challenged this view and proposed viewing Isocrates as the inventor of 'hypodeictic discourse' that he explains as 'joining narration with argument through praise by comparison', and Isocrates' тย́x $\nu \eta$ as innovatively consisting of longer examples and a technical commen-

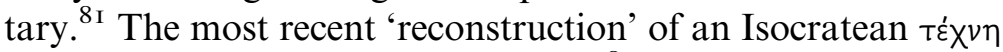
has been put forward by Walker. ${ }^{82}$ Walker's admittedly

$7^{8}$ E.g. To Nicocles 28, Helen 65, On the peace 4, Antidosis 274.

79 The evidence is collected in Radermacher (I95I), I53-63. Ancient references are summarized and discussed in Barwick (1963), who also gives a useful overview of the history of this question, and Walker (201I), 57-68. Both scholars arrive at completely opposite conclusions.

${ }^{80}$ Barwick (I963), 50. ${ }^{81}$ Papillon (I995), I59. ${ }^{82}$ Walker (20I I). 
speculative work argues, among other things, that Isocrates' TÉx $\eta$ was very similar to the Rhetoric to Alexander and that it also became a sort of ' $U r$-handbook' for all future sophistic or

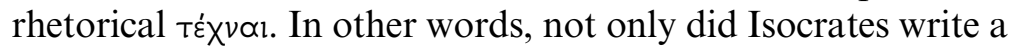
$\tau \varepsilon \dot{x} \vee \eta$, this work also became foundational for the subsequent rhetorical handbook tradition. ${ }^{83}$ Against Walker's extremely speculative account, I would like to make two points. Firstly, if Isocrates were indeed the founding father of the rhetorical handbook tradition, we would surely expect to hear more about that from our ancient sources. In fact, authorities in the field seem to question this attribution (e.g. Quintilian Inst. 2.I5.4: si tamen re vera ars quae circumfertur eius est). Hence, it could not have occupied such a central position in the rhetorical handbook tradition that Walker envisions if nothing at all was known about this work from relatively early on in the reception history. Secondly, contrary to what Walker suggests, one of the main characteristics of Isocrates that emerges is his uniqueness and dissimilarity from other (contemporary) teachers. This sense of difference is already articulated in the Phaedrus, where Socrates suggests that Isocrates is different from Lysias and the like, who could perhaps be grouped together with those writing handbooks and showing cleverness in little speeches like those that Phaedrus delivers in the dialogue. Indeed, in the handbook passage of the dialogue (266d-7d), Isocrates is not mentioned, whereas several others are mentioned as explicitly having written technai. Looking at the evidence we have about Isocrates' т́́x $\nu \eta$, it seems fairly clear that his contemporaries do not associate him with a rhetorical handbook tradition, and that this is something that becomes more prominent in later stages of his reception. ${ }^{84}$

83 Walker (20I I), 90.

${ }^{84}$ Roochnik (I996) examines the notion of 'techne' in philosophical tradition (mainly Plato) and proposes two ways to conceptualize this notion in ancient works: one would be the strict handbook approach $\left(\right.$ techne $\left._{1}\right)$ and another a more loose but difficult to express approach (techne $e_{2}$ ). He analyzes Isocrates' use of this term and concludes that Isocrates 'offers a techne ${ }_{2}$, a kind of teachable knowledge that makes none of the hard and fast claims of a techne, ' (288). This is possible, but perhaps rendered somewhat dubious by the fact that Isocrates himself makes no references to having ever produced such a work and, as has been persuasively 
The third argument about how to achieve Isocratean philosophy (Antidosis 275, quoted above) concerns the notion of

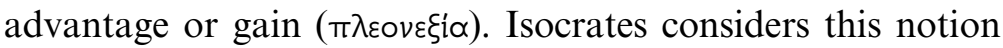
to be the most difficult of the points raised, because he has to argue against the widespread opinion according to which advantage is something achieved at the expense of others, either by robbing them or by doing other evil things $(28 \mathrm{I}){ }^{85}$ According to Isocrates, however, advantage in its true sense is applicable only to men 'who are the most righteous and most faithful in their devotions'. These men are also rewarded with advantage by their excellent associates and fellows. Why is it, all of a sudden, that common knowledge is actually not trustworthy and that there is a need to redefine the notion 'advantage'? Indeed, Isocrates' entire methodology seems to depend on the general trust in public opinion and widely held views. Isocrates realizes this problem and argues that there is a general misconception in Athens with regard to language and terminology used to denote certain activities and people. Meanings are turned upside-down, Isocrates claims, and buffoons capable of mocking and mimicking rather than men of

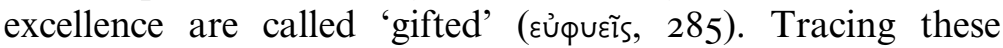
changes back to the so-called ancient sophists enables Isocrates to suggest that in reality he does not disagree with the general public, but with those 'philosophers' who have unhelpfully discredited the idea of 'advantage', which used to function as a positive term in the context of any intellectual activity. $^{86}$

We arrive here at what appears to be an explicit confrontation with Socrates and his teaching. It is a central characteristic of Socratic teaching to closely scrutinize one's reliance on, and appreciation of, external characteristics such as wealth and reputation regarded as goals in themselves (e.g. Apology

argued before, his corpus stands out by the amount of internal references made to his work within his own work. Why would Isocrates fail to mention a more programmatic work on his teaching principles if he had indeed authored one?

85 See also Antidosis 275, Nicocles 2, Peace 28-35.

86 This includes also an appraisal of the concept of wealth, for instance, that he claims has fallen into discredit amongst his contemporaries (Antidosis I59-60). 
3ob2-3). In the course of examining the true meanings of these characteristics, Socrates often ended up rethinking these terms in such a way that they acquired a meaning contrary to their original and literal sense: reputation ( $\delta$ ó $\xi \alpha)$ becomes mere appearance, the maxim 'help friends and hurt enemies' is turned upside-down, and so on. ${ }^{87}$ Isocrates takes issue with this approach and aims to return to the original or traditional meanings of these concepts and claims that his teaching will get the youth into the habit of striving towards advantage in relation to themselves and the country as a whole, and to do so in very concrete and practical terms. The challenge of the fundamental principles of Socratic teaching is not of secondary importance for Isocrates. In fact, rather than criticizing his contemporary intellectuals individually (Antisthenes, Plato, Aristotle, etc.) it could be argued instead that Isocrates treats them rather as a derivative or second-order group of Socratics, thus suggesting that Isocrates' most profound opponent, and one Isocrates is most committed to challenging in his works, is Socrates - the Athenian philosopher-teacher par excellence.

87 This is an oversimplification of the function of definitions in Plato's dialogues. See Politis (20I5) for a recent interpretation of the 'Tí દ̇ఠтl' question and Plato's method of inquiry in the early dialogues. 